\begin{tabular}{llrr}
\hline \hline Volume: & 3 & E-ISSN: & 2655-1942 \\
Number: & 1 & Terbitan: & April 2020 \\
Page : & $42-56$ & & \\
\hline
\end{tabular}

\title{
The Little Vatican: Optimalisisasi DWIPA (Desa Wisata Pancasila) sebagai Upaya Meningkatkan Harmonisasi Sosial dan Toleransi
}

\author{
Fradhana Putra Disantara, Dicky Eko Prasetio \\ Fakutas Ilmu Sosial dan Hukum, Universitas Negeri Surabaya, \\ Kampus UNESA Ketintang Surabaya \\ Email: dfradhana@gmail.com
}

\begin{abstract}
Abstrak
Gereja Stasi Santa Maria yang berada di Desa Kolong, Kecamatan Ngasem, Bojonegoro menjadi salah satu gereja yang unik karena selain digunakan sebagai tempat ibadah juga digunakan sebagai pusat kebudayaan masyarakat.Dengan demikian, integrasi antara agama dan budaya bisa menjadi salah suatu inisiasi dalam mewujudkan toleransi.Oleh karena itu, penelitian ini bertujuan untuk mendeskripsikan strategi integrasi agama dan budaya di masyarakat Desa Kolong, Kecamatan Ngasem, Bojonegoro dengan Gereja Stasi Santa Maria.Penelitian ini merupakan penelitian yuridis-normatif yang melihat berbagai peraturan hukum mengenai hak beragama dikaitkan dengan perilaku hukum masyarakat.Oleh karena itu, dalam penelitian ini lebih menekankan pada aspek penelitian kepustakaan (library research).Dari penelitian ini dapat disimpulkan bahwa praktik toleransi dapat dioptimalkan dengan adanya integrasi nilai-nilai budaya dengan agama serta perlunya optimalisasi Desa Wisata Pancasila sebagai solusi untuk meningkatkan toleransi dan harmonisasi social di masyarakat.
\end{abstract}

Kata Kunci: Hak Beragama, Kebudayaan, dan Toleransi.

\begin{abstract}
The St. Maria Stasi Church in Kolong Village, Ngasem District, Bojonegoro is a unique church because besides being used as a place of worship it is also used as a cultural center for the community. Thus, the integration between religion and culture can be an initiation in realizing tolerance. Therefore, this study aims to describe the strategy of integration of religion and culture in the community of Kolong Village, Ngasem District, Bojonegoro with the St Maria Church. This research is a normative legal research which looks at various legal regulations regarding religious rights related to community legal behavior. Therefore, in this study the emphasis is more on aspects of library research. From this study it can be concluded that the practice of tolerance can be optimized by the integration of cultural values with religion and the need for optimization of the Pancasila Tourism Village as a solution to increase tolerance and social harmony in society.
\end{abstract}

Keywords: Religion right, Culture, and Tolerantion.

\section{A. Latar Belakang Masalah}

Agama sebagai tuntunan nilai-nilai dan perilaku dalam kehidupan manusia sejatinya telah menjangkau dua segi utama kehidupan manusia, yaitu segi spiritual dan sosial. Dalam segi spiritual, agama menjangkau pada aspek hubungan religiusitas antara manusia sebagai individu dengan Tuhan Yang Maha Esa sebagai sang pencipta. Sedangkan dalam aspek sosial, agama termanifestasikan sebagai rasa cinta, kasih, tolong-menolong, serta toleransi khususnya kepada sesama manusia.Sehingga tidak 


\begin{tabular}{llrr}
\hline \hline Volume: & 3 & E-ISSN: & $2655-1942$ \\
Number: & 1 & Terbitan: & April 2020 \\
Page : & $42-56$ & & \\
\hline
\end{tabular}

jarang dalam segi sosial agama seringkali berkorelasi dengan budaya, bahkan tak sedikit pula hal tersebut dapat menghasilkan konflik horizontal dalam kehidupan masyarakat.Indonesia sebagai religious nation state ${ }^{l}$ yang mengedepankan nilai-nilai agama sebagai causa prima dalam kehidupan manusia telah mengukuhkan pentingnya nilai-nilai agama guna disinergikan dengan nilai-nilai lainnya di dalam masyarakat, termasuk nilai budaya dan nilai kebangsaan.Di Indonesia, terdapat 207.176.162 $(87,18 \%)$ penduduk Indonesia yang beragama Islam, $16.528 .513(6,96 \%)$ penduduk Indonesia yang beragama Kristen, 6.907 .873 (2,91\%) yang beragama Katolik, 4.012.116 (1,69\%) yang beragama Hindu, $1.703 .254(0,72 \%)$ yang beragama Budha, $117.091(0,05)$ yang beragama Konghucu, dan lainnya sejumlah $299.617(0,13)$.

Adanya keberagaman dalam hal agama di Indonesia, justru menyisakan beberapa polemik, khususnya terkait dengan isu-isu agama yang sering digunakan dalam aspek politik praktis, tindak kekerasan, bahkan terkait dengan terorisme. Hal ini dapat dilihat bahwa saat ini toleransi menjadi sesuatu yang sulit diwujudkan di Indonesia, dan justru sebaliknya praktik intoleransi justru berkembang dan semakin banyak di Indonesia. Hal ini dapat dibuktikan bahwa tingkat kebebasan beragama dan toleransi di Indonesia sebagaimana yang dilaporkan oleh Sosial Progress Imperativeyang memperhatikan tiga faktor yaitu: basic human needs, foundation of well being, dan opportunity untuk kemudian dijumlahkan dengan angka 100 sebagai angka tertinggi. Skor yang di dapat Indonesia padatahun 2014 mencapai adalah 27,90, dan tahun 2015 naik menjadi 32,30. Namun skor ini turun pada tahun 2016 menjadi 29,57 yang kemudian naik lagi pada tahun 2017 menjadi 35,47\%. Kemudian pada tahun 2018 sampai pada pertengahan 2019, skor kembali naik pada angka 63.86\%.Meski mengalami perkembangan, namun secara keseluruhan Indonesia masih berada pada posisi 91dari 146 negara. Bila dirinci, dari lima subkomponenpersonal rights, skor pada 'kebebasan beragama' hanya sebesar 2,54. Data Democracy Index dari The Economist Intelligence Unitjuga menekankan bahwa salah satu masalah intoleransi terbesar adalah berkaitan dengan masalah-masalah demokrasi dan politik. Dari data yang dirilis oleh The Economist Intelligence

\footnotetext{
${ }^{1}$ Abdullah, "Hubungan Agama dan Negara: Konteks Ke-Indonesiaan”, Jurnal Politik Profetik, Vol. 4, No. $2,2014$.
} 


\begin{tabular}{llrr}
\hline \hline Volume: & 3 & E-ISSN: & 2655-1942 \\
Number: & 1 & Terbitan: & April 2020 \\
Page : & $42-56$ & & \\
\hline
\end{tabular}

Unittersebut, menggambarkan bahwaindeks demokrasi di Indonesia mengalami penurunan dari yang tahun 2014 yaitu 6,94, tahun 2015 menjadi 7,03, dan 2016 menjadi 6,97, serta penurunan paling jelas terjadi tahun 2017 yang hanya mencapai 6,39.

Meski menyisakan berbagai problem di masyarakat, adanya keberagaman dan hak kebebasan beragama sejatinya merupakan amanat dari Konstitusi Undang-Undang Dasar Negara Republik Indonesia 1945 (UUD NRI 1945) Pasal 29 Ayat (2) yang berbunyi "Negara menjamin kemerdekaan tiap-tiap penduduk untuk memeluk agamanya masing-masing dan untuk beribadat menurut agamanya, dan kepercayaanya itu”. Bukan hanya itu, legitimasi kebebasan beragama juga termaktub pada Pasal 18 Universal Declaration of Human Rights 1948 (Deklarasi Universal Hak-Hak Asasi Manusia)yang menyatakan "Setiap orang berhak atas kebebasan pikiran, hati nurani dan agama; dalam hal ini termasuk kebebasan berganti agama atau kepercayaan, dengan kebebasan untuk menyatakan agama atau kepercayaann dengan cara mengajarkannya, melakukannya, beribadat dan mentaatinya, baik sendiri maupun bersama-sama dengan orang lain, di muka umum maupun sendiri”.Adanya jaminan kebebasan beragama dalam konstitusi nasional serta rekognisi dari dunia internasional tersebut merupakan perwujudan prinsip hak asasi manusia dimana hak beragama merupakan hak yang bersifat non-derogable right ${ }^{2}$. Sekalipun secara umum toleransi beragama sulit diwujudkan, namun di salah satu desa di Kabupaten Bojonegoro yaitu di Desa Kolong Kecamatan Ngasem, terdapat Gereja Katolik Stasi Maria yang merupakan salah satu gereja tertua di Bojonegoro dan menjadi salah satu tempat penyebaran Agama Katolik di Bojonegoro. Meskipun keberadaan gereja ini berada bersebelahan dengan masjid, namun tidak pernah dijumpai adanya hal-hal yang bersifat negatif seperti kerusuhan, diskriminasi Suku, Agama, Ras, dan Antar-golongan (SARA), serta stratifikasi sosial. Masyarakat desa tersebutjustru cukup terbuka dan memiliki rasa toleransi terkait perbedaan agama dan tidak pernah mempermasalahkan adannya perbedaan SARA. Hal ini dibuktikan pada acara kebaktian yang dilakukan oleh masyarakat Katolik di gereja tersebut, terdapat seperangkat alat musik gamelanyang

\footnotetext{
${ }^{2}$ Galuh Candra Purnamasari, "Problematik Penerapan Aturan Pembatasan Hak Asasi Manusia dalam Konstitusi Indonesia”, Jurnal Prioris,Vol. 6, No. 2, 2017.
} 


\begin{tabular}{llrr}
\hline \hline Volume: & 3 & E-ISSN: & 2655-1942 \\
Number: & 1 & Terbitan: & April 2020 \\
Page : & $42-56$ & & \\
\hline
\end{tabular}

dimainkan oleh masyarakat yang mayoritas beragama Islam untuk mengiringi dalam proses kegiatan tersebut. Selain itu, pada hari Natal, seluruh warga Desa Kolong baik yang beragama Katolik, Islam maupun yang beragama lain juga ikut merayakan dengan adanya bakti sosial dan pengobatan gratis yang sering diadakan oleh pihak gereja yang bekerja sama dengan Pemerintah Kabupaten Bojonegoro. Desa Kolong dengan Gereja Stasi Santa Maria telah menjadi salah satu platform dalam upaya untuk menjalankan praktik toleransi serta memperkuat gagasan civic society di Indonesia. Artinya, gagasan harmonisasiantara agama dan budaya di gereja tersebut menjadi salah satu contoh bagi masyarakat Indonesia agar menerapkan prinsip toleransi dan meningkatkan kesadaran beragama dalam bingkai persatuan Indonesia berdasarkan atas dasar Pancasila.

Penelitian ini terinspirasi dari dua penelitian sebelumnya yaitu: pertama, penelitian yang dilakukan oleh RinaHermawati, Caroline Paskarina, dan NunungRuniawati (2016) tentang Toleransi Antar Umat Beragama di Kota Bandung. Penelitian mengenai toleransi antar umat beragama di Kota Bandung tersebut menekankan pada upaya untuk menghindari dan mencegah timbulnya konflik antar umat beragama di Kota Bandung. ${ }^{3}$ Oleh karena itu, pendekatan yang digunakan adalah pendekatan antropologis dengan metode kuantitatif serta mengetengahkan solusi berupa perbaikan mekanisme izin pembangunan rumah ibadah untuk menjaga harmonisasi sosial di Kota Bandung. Kedua, penelitian yang dilakukan oleh Rubiyatul Adawiyah, M. Mansur, dan Trisakti Handayani (2019) tentang Analisis Penerapan Pendidikan Multikultural Dalam Menciptakan Toleransi Antar Umat Beragama. Penelitian tersebut berfokus pada pengembangan metode pembelajaran sikap toleransi di lingkungan sekolah, khusunya di SMP Immanuel Batu.Pengumpulan data dalam penelitian tersebut dilakukan dengan observasi, wawancara, dan dokumentasi dengan simpulan penelitian berupa pentingnya upaya untuk merekonstruksi pola pendidikan toleransi dalam metode pembelajaran siswa supaya didapatkan sikap toleransi dan saling menghargai antar siswa di sekolah serta dapat diterapkan di lingkungan masyarakat. ${ }^{4}$ Penelitian ini

\footnotetext{
${ }^{3}$ RinaHermawati, Caroline Paskarina, dan NunungRuniawati, "Toleransi Antar Umat Beragama di Kota Bandung”, Jurnal Umbara, Vol. 1, No. 2, 2016.

${ }^{4}$ Rubiyatul Adawiyah, M. Mansur, Trisakti Handayani, "Analisis Penerapan Pendidikan Multikultural Dalam Menciptakan Toleransi Antar Umat Beragama”, Jurnal Civic Hukum, Vol. 4, No. 1, 2019.
} 


\begin{tabular}{llrr}
\hline \hline Volume: & 3 & E-ISSN: & 2655-1942 \\
Number: & 1 & Terbitan: & April 2020 \\
Page : & $42-56$ & & \\
\hline
\end{tabular}

berbeda dengan dua penelitian sebelumnya karena, (i) penelitian yang penulis lakukan berorientasi pada perspektif yuridis dengan mengaitkan kepada konvensi atau peraturan perundang-undangan yang terkait, (ii) objek penelitian berada di Desa Kolong, Kecamatan Ngasem, Bojonegoro, serta (iii) simpulan dari penelitian ini bertujuan untuk mengimplementasikan peningkatan akan kesadaran toleransi beragama dengan optimalisasi Desa Wisata Pancasila. Berdasarkan tiga perbedaan tersebut, maka penelitian ini merupakan penelitian yang orisinil serta berbeda dengan dua penelitian sebelumnya. Dengan demikian, maka rumusan masalah dalam penelitian ini yaitu: (i) Bagaimana kondisi toleransi beragama di Desa Kolong, Kecamatan Ngasem, Bojonegoro?, dan (ii) Bagaimana optimalisasi peningkatan toleransi beragama di Desa Kolong, Kecamatan Ngasem, Bojonegoro ke depan?

\section{B. Metode Penelitian}

Penelitian ini merupakan penelitian yuridis-normatif. Penelitian hukum merupakan penelitian yang berfokus pada norma dan perilaku hukum masyarakat. ${ }^{5}$ Penelitian hukum bertujuan untuk mencari suatu preskrispi atau apa yang seyogyanya dilakukan.Data yang digunakan dalam tulisan ini yaitu data sekunder, dengan penggunaan bahan hukum meliputi bahan hukum primer, sekunder dan bahan non hukum. ${ }^{6}$ Dalam penelitian ini digunakan dua bahan hukum yaitu bahan hukum primer dan bahan hukum sekunder ${ }^{7}$. Bahan hukum primer dalam penelitian ini dapat berupa konvensi internasional tentang hak asasi manusia terutama menyangkut tentang kebebasan beragama serta Undang-Undang Dasar dan Undang-Undang yang terkait tentang kebebasan beragama.Sedangkan bahan hukum sekunder dapat berupa buku dari para ahli hukum maupun jurnal ilmiah yang ditulis oleh para ahli hukum.

\section{Hasil Penelitian dan Pembahasan}

\section{Gereja Stasi Santa Maria Kolong dan Praktik Toleransi}

Desa Kolong merupakan salah satu desa di Kabupaten Bojonegoro yang memiliki budaya unik dalam toleransi beragama yang telah berakar dan turun-temurun dilakukan

\footnotetext{
5 Jonaedi Efendi dan Johnny Ibrahim, 2016, Metode Penelitian Hukum Normatif dan Empiris, Prenadamedia Grup, Jakarta.

${ }^{6}$ Ibid.

${ }^{7}$ Kornelius Benuf and Muhamad Azhar, 'Metodologi Penelitian Hukum Sebagai Instrumen Mengurai Permasalahan Hukum Kontemporer', Gema Keadilan, 7.1 (2020), 20-33.
} 


\begin{tabular}{llrr}
\hline \hline Volume: & 3 & E-ISSN: & 2655-1942 \\
Number: & 1 & Terbitan: & April 2020 \\
Page : & $42-56$ & & \\
\hline
\end{tabular}

oleh masyarakat Desa Kolong.Proses toleransi beragama yang dilakukan oleh masyarakat Desa Kolong bermula ketika di desa tersebut didirikan Gereja Stasi Santa Maria. Gereja tersebut merupakan $\operatorname{stasi}^{8}$ tertua di ParokiBojonegoro yang terletak45 Km dari pusat KabupatenBojonegoro.Perintisnya adalah FX Sukimin atau yang lebih dikenal dengan 'Mbah Danun'. Pada tahun 1941, FX Sukimin mulai mengajar agama dan mendirikan sebuah kapel kecil di kampung halamannya yang diberi nama 'BronoKaswargaan'. Pada tahun 1951 Paroki Santo Wilibrordus Cepu menetapkannya sebagai stasi, dan menugaskan Hartono sebagai katekisdi sana. Umat yang mengikuti pelajaran pada waktu itu belum begitu banyak, kira-kira hanya sembilan orang.Dengan diresmikannya Santo Paulus Bojonegoro, maka pembinaannya diserahkan kepada Paroki Bojonegoro. Tugas katekisasi dilanjutkan oleh Suparno, FVAJ Senen, Tedjohono, Ai PututSunardjo, Ninik SP, Sujito, dan F. Sarman. Perkembangan umat di Stasi Santa Maria Kolong mendapat perhatian dari Romo Ernesto, maka pada tahun 1987 di atas tanah pemberian Mbah Danun didirikan sebuah gereja baru dengan pelindung Santa Maria. ${ }^{9}$

Disamping Gereja Stasi Santa Maria, tepatnya dalam jarak 70 meter berdirilah Masjid Al Ihsan, yang notabene menjadi tempat ibadah umat Islam Desa Kolong. Akan tetapi, hal tersebut tidak menimbulkan permusuhan dan perpecahan antar umat beragama di Desa Kolong, justru masyarakat yang beragama Islam dan beragama Katolik saling bahu-membahu untuk membantu sesama.Sensitivitas SARA-pun sangat dijaga oleh masyarakat setempat dengan menghargai sesama. Tidak ada yang dilakukan oleh sesama warga masyarakat Desa Kolong terkait pembatasan, pelecehan, atau pengucilan yang langsung ataupun tak langsung didasarkan pada pembedaan manusia atas dasar agama yang berakibat penyimpangan, pengurangan, atau penghapusan pengakuan, pelaksanaan, atau penggunaan hak asasi manusia dan kebebasan dasar dalam kehidupan baik individual maupun kolektif dalam bidang politik, hukum, sosial, ekonomi, budaya dan aspek kehidupan lainnya.Suasana tersebut sangat berbeda

\footnotetext{
${ }^{8}$ Carolina Prolensia dan Don BoscoKarnanArdijanto, "Pemahaman Umat Katolik Di Stasi ST. Yosef Karangrejo, Paroki Regina PacisMagetan Tentang Kebangkitan Badan dan Kehidupan Kekal dalam Ajaran Gereja Katolik", Jurnal Pendidikan Agama Katolik, Vol. 20, No. 10, 2018.

${ }^{9}$ Tim Penyusun Paroki ST Paulus Bojonegoro, Buku Kenangan Pesta Emas Paroki ST Paulus Bojonegoro, Paroki ST Paulus Bojonegoro, Bojonegoro, 2011.
} 


\begin{tabular}{llrr}
\hline \hline Volume: & 3 & E-ISSN: & 2655-1942 \\
Number: & 1 & Terbitan: & April 2020 \\
Page : & $42-56$ & & \\
\hline
\end{tabular}

ditengah hingar bingar perpolitikan di Indonesia, mulai dari Pemilihan Kepala Daerah serentak 2018 hingga Pemilihan Umum serentak 2019, sensitivitas SARAdijadikan sebagai cara 'mujarab' untuk meraih pundi-pundi suara. Namun,dibalik suksesnya caracara dengan mengandalkan sensitivitas SARA untuk meraih kemenangan dalam kontestasi politik, setali tiga uang dengan hal tersebut, dampak yang ditimbulkan oleh adanya politik SARA yang kemudian disebut sebagai politik identitas adalah adanya disharmonisasi sosial yang dapat berakibat pada perpecahan, permusuhan, saling menebar rasa kebencian, hingga polarisasi masyarakat akibat adanya berbagai kubu yang berseteru. Padahal, pelarangan atas tindakan yang menganjurkan kebencian atas dasar kebangsaan, ras atau agama yang merupakan hasutan untuk melakukan tindak diskriminasi, permusuhan atau kekerasan telah tercantum dalam Pasal 20 Ayat (2) International Covenant on Civil and Political Rightsatau yang biasa disebut dengan Kovenan Internasional tentang Hak-hak Sipil dan Politik.Hal ini, kemudian telah membawa persepsi buruk terhadap adanya keberagaman, bahkan asumsi bahwa "the danger of diversity" dapat memperkeruh tata kehidupan masyarakat dapat relasi sosial menjadi tidak terelakkan.Apabila hal tersebut benar-benar terjadi di Indonesia, maka pertanyaan selanjutnya adalah, quo vadis Pancasila?

Saat ini, secara umum aktualisasi harmonisasi dan toleransi antarumat beragama didasari dengan pemahaman dan penafsiran yang kurang mendalam terhadap suatu ajaran agama yang dianut, sehingga menjadikan agama hanya dianggap sebagai sarana 'ritual-formal-prosedural' semata yang berdampak pada siapa saja yang tidak mengikuti 'ritual-formal-prosedural' maka dianggap bukan bagian dari agamanya. Pemahaman agama yang 'sempit' ini semakin memperlebar jarak dan garis demarkasi antarumat beragama, sehingga adanya berbagai konflik horizontal di masyarakat menjadi tidak terelakkan. Selain itu, adanya konflik beragama juga merupakan bagian yang integral dari sistem politik saat ini yang lebih menekankan aspek politik identitas ${ }^{11}$ sebagai 'senjata'.Politik identitas berdasarkan atas SARA menjadi senjata para politisi untuk

\footnotetext{
${ }^{10}$ Gina Lestari, "Bhinnekha Tunggal Ika: Khasanah Multikultural Indonesia Di Tengah Kehidupan Sara", Jurnal Pendidikan Pancasila dan Kewarganegaraan, Vol. 28, No. 1, 2015.

${ }^{11}$ JuhanaNasrudin dan Ahmad Ali Nurdin, "Politik Identitas dan Representasi Politik (Studi Kasus Pada Pilkada DKI Periode 2018-2022)", Jurnal Hanifiya, Vol. 1, No. 1, 2018.
} 


\begin{tabular}{llrr}
\hline \hline Volume: & 3 & E-ISSN: & 2655-1942 \\
Number: & 1 & Terbitan: & April 2020 \\
Page : & $42-56$ & & \\
\hline
\end{tabular}

memuluskan langkah mendapatkan jabatan-jabatan yang diinginkan tanpa harus memperhatikan kualitas, kapasitas, dan kapabilitas dirinya masing-masing.Semakin menurun dan rendahnya tingkat toleransi masyarakat Indonesia saat ini, terlebih lagi dengan semakin massifnya penggunaan media sosial yang justru terkadang semakin memperkeruh suasana keharmonisan antarumat beragama dengan hoaksserta ujaran kebencian ${ }^{12}$ yang terus digaungkan oleh oknum-oknum yang tidak bertanggung jawab.Akan tetapi, keberadaan gereja yang memiliki kedekatan dengan masjid justru membuat masyarakat Desa Kolong menjadi lebih mudah untuk membaur dalam kehidupan sosialnya tanpa membedakan status agama,sehingga membuat masyarakat Desa Kolong hidup dengan penuh kerukunan dan ketentraman. Hal ini sesuai dengan butir-butir Pancasila sila pertama butir keempat, yakni membina kerukunan hidup di antara sesama umat beragama dan kepercayaan terhadap Tuhan Yang Maha Esa. Bukan hanya itu, upaya harmonisasi juga diperlihatkan di Gereja Stasi Santa Maria Kolong dengan memberikan peran kepada umat Islam untuk pada saat kebaktian maupun saat hari-hari besar keagamaan telah mengubah ekslusivitas sebuah agama.

\section{The Little Vatican: Optimalisasi Desa Kolong sebagai Desa Wisata Pancasila}

Nilai-nilai agama bersifat universal, sehingga antar satu agama dengan agama yang lain yang membedakan hanya masalah 'ritual' dan aspek ibadahnya saja. ${ }^{13}$ Pasal 4 Undang-Undang Nomor 39 tahun 1999 tentang Hak Asasi Manusia menyatakan bahwa hak beragama adalah salah satu hak yang tidak dapat dikurangi dalam keadaan-keadaan apapun dan oleh siapapun. Adanya akses kebebasan bagi para pemeluk agama untuk tidak di-diskriminasi dalam bidang apapun merupakan refleksi dari asas keadilan. Sehingga, kebebasan dan perbedaan beragama adalah hak setiap manusia, bahkan hal ini bukan menjadi alasan untuk bermusuhan atau terjadinya diskriminasi, akan tetapijustru dijadikan pilar-pilar untuk memperkuat sendi-sendi bangsa. Oleh karena itu, apa yang dilakukan oleh Gereja Stasi Santa Maria Kolong dengan kesenian gamelannya nyatanya telah memberikan suatu penyadaran konsepsi bagi semua masyarakat beragama bahwa salah satu cara yang terbaik untuk mewujudkan toleransi adalah

\footnotetext{
${ }^{12}$ Dian JunitaNingrum, Suryadi, dan Dian Eka Chandra Wardhana, "Kajian Ujaran Kebencian Di Media Sosial", Jurnal Ilmiah Korpus, Vol. 2, No. 3, 2018.

${ }^{13}$ Amri Marzali, “Agama dan Kebudayaan”, Jurnal Umbara, Vol. 1, No. 1, 2016.
} 


\begin{tabular}{llrr}
\hline \hline Volume: & 3 & E-ISSN: & 2655-1942 \\
Number: & 1 & Terbitan: & April 2020 \\
Page : & $42-56$ & & \\
\hline
\end{tabular}

harmonisasi.Harmonisasi yang paling terbaik serta efektif adalah harmonisasi dengan budaya sebagai hasil rasa, cipta, dan karsa masyarakat yang memiliki nilai universal.Adanya gereja tersebut perlu mendapat konstruksi-konstruksi modernismsupaya dapat mengefektifkan peran dan upaya gereja tersebut untuk mewujudkan toleransi beragama serta menjadi "The Little Vatican in Indonesia".Dalam aspek teoretis, apa yang telah dilakukan oleh Gereja Stasi Santa Maria Kolong merupakan bagian integral dari konsep civic society dan social capital. Civic society berasal dari bahasa latin yaitu societies civiles yang pertama kali dikemukakan oleh Cicero yang berarti sekelompok masyarakat yang mendominasi sekelompok masyarakat lain. ${ }^{14} \mathrm{Di}$ Indonesia, gagasan civic society dikenal dengan gagasan masyarakat madani. ${ }^{15}$ Masyarakat madani adalah suatu kondisi masyarakat yang ideal dengan ciri utamanya yaitu adanya pengakuan terhadap jaminan hak asasi manusia, penghargaan atas perbedaan SARA, dan adanya usaha bersama antara pemerintah, swasta, dan masyarakat dalam kehidupan bernegara.Penerapan konsepsi masyarakat madani yang dilakukan oleh masyarakat Desa Kolong, khususnya dengan adanya Gereja Stasi Santa Maria Kolong merupakan salah satu upaya untuk semakin merekatkan masyarakat terhadap berbagai perbedaan serta upaya untuk mengharmonikan masyarakat melalui adanya cultural approach ${ }^{16}$ seperti yang dilakukan Gereja Stasi Santa Maria Kolong dengan adanya kesenian gamelan.Sehingga, dengan adanya pendekatan kebudayaan, penerapan civic society tidak hanya terbatas hanya sekadar adanya pengakuan hak asasi manusia, khususnya hak beragama, melainkan juga sebagai upaya penjaminan tata kehidupan masyarakat yang harmonis sehingga jiwa dan karakter bangsa dapat terbentuk di mana bukan hanya penjaminan hak asasi manusia yang bersifat individual, melainkan penjaminan hak asasi manusia yang berjiwa komunal, kekeluargaan, dan

\footnotetext{
${ }^{14}$ Nuraini Latuconsina,"Perkembangan Demokrasi dan Civil Society di Indonesia”. Jurnal Populis, Vol. 7, No. 2, 2013.

${ }^{15}$ Latifah dan Dinda Larasati, "Demokrasi dan Organisasi Masyarakat Sipil: Malang Corruption Watch", Jurnal Sospol, Vol. 4, No. 1, 2018.

${ }^{16}$ Anthony A. Volka, Katerina Schirallia, XiaoyangXiab, JunruZhaoc, dan Andrew V. Dane, "Adolescent bullying and personality: A cross-cultural approach", Personality and Individual Differences Journal, Vol. 125, Vol. 1, 2018.
} 


\begin{tabular}{llrr}
\hline \hline Volume: & 3 & E-ISSN: & $2655-1942$ \\
Number: & 1 & Terbitan: & April 2020 \\
Page : & $42-56$ & & \\
\hline
\end{tabular}

berjiwa welfare state $^{17}$ dalam kerangka Pancasila. Dalam konsep social capital yang menekankan adannya hubungan-hubungan sosial dalam masyarakat yang bersifat tidak nampak (intangible), namun memiliki dampak yang sangat besar dalam masyarakat, ${ }^{18}$ adanya Gereja Stasi Santa Maria Kolong menunjukkan adanya penerapan konsep social capital dalam hidup bermasyarakat dengan menekankan adanya harmoni dalam kehidupan beragama dengan budaya sebagai 'senjata' utamanya. Keberadaan gereja tersebut apabila dikaitkan dengan konsepsi social capital adalah munculnya harmonisasi kehidupan beragama dan bermasyarakat dengan budaya sebagai objek perekat, maka dapat menimbulkan adanya kepercayaan (trust) atau nilai-nilai positif yang menghargai perkembangan dalam masyarakat. Nilai-nilai positif tersebut dapat dillihat sebagai suatu tradisi gotong-royong, sambatan, dan saling kerja sama tanpa memandang aspek SARA dalam kehidupan bermasyarakat. Nilai ini diharapkan pula dapat berkembang dan diterapkan oleh masyarakat Indonesia supaya moral value dari sila ketiga Pancasila yaitu "Persatuan Indonesia" dapat diwujudkan.Selain itu, adanya rasa toleransi yang tinggi di masyarakat juga dapat menimbulkan adanya kesadaran norma-norma sosial yang tinggi di masyarakat. Hal ini dapat berdampak pada semakin taatnya masyarakat akan hukum, meski tanpa adanya paksaan dari instansi yang berwenang, seperti halnya tidak adanya tindak pidana penodaan atau penistaan agama yang diakibatkan oleh sikap fanatisme buta seorang penganut agama tertentu, tidak akan pernah terjadinya kerusuhan atau saling bakar rumah ibadah hanya gara-gara saling curiga dan saling tuduh atas adanya tindakan terorisme, dan semaikin dilaksanakannya penerapan nilai-nilai norma di dalam masyarakat diantaranya: norma agama, norma hukum, norma kesusilaan, dan norma kesopanan. Selanjutnya, bahwa dengan semakin kuatnya jiwa toleransi di masyarakat dapat menimbulkan adanya social networkingyang saling menguntungkan, salah satu contohnya adalah penjagaan tempat ibadah umat muslim (masjid) saat hari raya Idul Fitri oleh pemuda Katolik, dan sebaliknya penjagaan tempat ibadah umat Katolik (gereja) saat Natal oleh pemuda-pemuda muslim.

Dalam termonologi social capital setidaknya akan memberikan sebuah dampak

\footnotetext{
${ }^{17}$ Muhammad Kambali, "Paradigma Sistem Kapitalisme dan Islam Tentang Welfare State", Jurnal JES, Vol. 3, No. 2, 2019.

${ }^{18}$ Sunyoto Usman, 2018, Modal Sosial, Pustaka Pelajar, Yogyakarta.
} 


\begin{tabular}{llrr}
\hline \hline Volume: & 3 & E-ISSN: & 2655-1942 \\
Number: & 1 & Terbitan: & April 2020 \\
Page : & $42-56$ & & \\
\hline
\end{tabular}

dalam tataran norma (norm) termasuk norma sosial, kepercayaan masyarakat (trust) serta adanya jejaring sosial (social networking) dalam masyarakat yang memiliki hubungan bersifat reciprocal atau timbal balik dan saling menguntungkan. Sehingga, adanya Gereja Stasi Santa Maria Kolong dapat menjadi platform atau role model dalam menyikapi keberagaman dan pluralisme bangsa Indonesia sebagai karunia Tuhan Yang Maha Esa untuk dapat dioptimalkan untuk mencapai tujuan-tujuan dalam social capital (modal sosial). Dalam hal ini, maka perlu inisiasi-inisiasi untuk meningkatkan peran dan fungsi adanya Gereja Stasi Santa Maria Kolong khususnya kepada masyarakat Desa Kolongdan sebagai role model bagi Indonesia pada umumnya dalam menyikapi keberagaman dengan toleransi dan harmonisasi sosial dalam bermasyarakat. Dalam hal ini, untuk meningkatkan optimalisasi adanya Gereja Stasi Santa Maria Kolong, perlu diadakan langkah-langkah berikut diantaranya: Pertama, meningkatkan peran harmonisasi budaya di Gereja Stasi Santa Maria Kolong yang sudah terlaksana dengan adanya alat musikgamelan, yang bisa ditingkatkan menjadi pusat pembelajaran karawitan dan bisa ditammbah dengan kesenian-kesenian rakyat lainnya seperti tayuban, wayang kulit, ludruk, ketroprak, serta kesenian lainnya yang memiliki muatan nilai-nilai moral tentang toleransi dalam masyarakat. Kedua, perlunya pemberdayaan Tolerantion Tourism (double T) yang bisa dijadikan objek wisata pembelajaran toleransi dengan konsep DWIPA (desa wisata Pancasila) yang bisa dilakukan dengan pemasangan photo boot dengan tulisan-tulisan yang mampu meningkatkan rasa toleransi, pembuatan Taman Baca Pancasila (TBC), adanya diskusi lintas agama dan budaya secara berkala, dan paket wisata khusus living harmony, yaitu hidup bersama dan merasakan hidup dengan masyarakat Desa Kolong yang dekat dengan Gereja Stasi Santa Maria Kolong dengan adanya fasilitas penginapan. Ketiga, perlu dibuatkan sentra Usaha Kecil Menengah (UKM) baik kuliner atau souvenir untuk mendukung terselenggaranya desa wisata Pancasila yang selain dapat meningkatkan rasa toleransi juga sekaligus meningkatkan perekonomian masyarakat setempat.Keempat, perlunya dukungan dari berbagai bidang lintas sektoral baik itu masyarakat, pengusaha, dan pemerintah. Khususnya untuk pemerintah desa diharapkan dapat membantuk terwujudnya DWIPA (desa wisata Pancasila) dengan mengambil konsep "The Little 


\begin{tabular}{llrr}
\hline \hline Volume: & 3 & E-ISSN: & 2655-1942 \\
Number: & 1 & Terbitan: & April 2020 \\
Page : & $42-56$ & & \\
\hline
\end{tabular}

Vatikan" melalui bantuan dana desa. Konsep The Little Vatikan dimaksudkan sebagai pusat pembelajaran keagamaan (dalam hal ini Katolik) sekaligus sebagai pusat kajian kebudayaan. Istilah "little Vatikan" merujuk pada Negara Vatikan sebagai pusat agama Katolik di dunia sekaligus sebagai pusat agama yang paling aktif menggemakan toleransidan perdamaian dunia. Terkait dengan konsep The Little Vatikan yang dapat diterapkan dalam Desa Wisata Pancasila lebih diorientasikan kepada optimalisasi pusat kajian keagamaan sekaligus sebagai pusat kajian toleransi dan keberagaman di tingkat desa, hal ini juga lebih optimal jika dikonstruksikan dengan kesenian atau budaya lokal masyarakat yang bernuansa nilai-nilai toleransi, kebaikan, serta ajakan untuk menjaga persatuan dan kesatuan bangsa.

Diharapkan, beberapa solusi dan tawaran gagasan tersebut dapat menjadi upaya bagi masyarakat Desa Kolong dan kepada bangsa Indonesia. Hal diatas menunjukkan bahwa harmonisasi agama dan budaya dalam kehidupan bermasyarakat tentang penanaman nilai-nilai Pancasila menjadi sangat penting yang mana salah satu solusi yang dapat diaktualisasi adalah melalui DWIPA (desa wisata Pancasila).

\section{Kesimpulan}

Adanya Gereja Stasi Santa Maria di Desa Kolong, Kecamatan Ngasem, Kabupaten Bojonegoro yang memiliki jarak yang dekat dengan Masjid Al Ikhsan memunculkan harmonisasi antara agama dan budaya dalam masyarakat setempat, sehingga membuat budaya toleransi di desa ini sudah mendarah daging serta merupakan bagian dari kehidupan masyarakat. Hal ini dapat dioptimalisasikan dengan adanya DWIPA (desa wisata Pancasila) dengan konsep "The Little Vatikan" dengan beberapa gagasan dan inisiasi. Pertama, dengan peningkatan fungsi gereja yang hanya sekedar acara keagamaan dengan kesenian gamelan bisa ditambah dengan kesenian-kesenian lain seperti: tayuban, wayang kulit, ludruk, ketroprak, serta kesenian lainnya yang dapat juga diisi nilai-nilai moral tentang toleransi dalam masyarakat. Kedua, pemberdayaan Tolerantion Tourism (double T) dengan adanya DWIPA (desa wisata Pancasila) dengan konsep "The Little Vatikan". Ketiga, pembuatan sentra UKM-UKM baik kuliner atau souvenir untuk mendukung terselenggaranya desa wisata Pancasila yang selain dapat 


\begin{tabular}{llrr}
\hline \hline Volume: & 3 & E-ISSN: & 2655-1942 \\
Number: & 1 & Terbitan: & April 2020 \\
Page : & $42-56$ & & \\
\hline
\end{tabular}

meningkatkan rasa toleransi juga sekaligus meningkatkan perekonomian masyarakat setempat. Keempat, perlunya dukungan dari berbagai bidang lintas sektoral baik itu masyarakat, pengusaha, dan pemerintah. Khususya pemerintah desa dengan optimalisasi dana desa untuk pengembangan DWIPA (desa wisata Pancasila) dengan konsep "The Little Vatican"

\section{Daftar Pustaka}

\section{Buku:}

Efendi, Jonaedi dan Johnny Ibrahim, 2016, Metode Penelitian Hukum Normatif dan Empiris, Prenadamedia Grup, Jakarta.

Tim Penyusun Paroki ST Paulus Bojonegoro, Buku Kenangan Pesta Emas Paroki ST Paulus Bojonegoro, Paroki ST Paulus Bojonegoro, Bojonegoro, 2011.

Usman, Sunyoto, 2018, Modal Sosial, Pustaka Pelajar, Yogyakarta.

\section{Artikel Jurnal:}

Abdullah, "Hubungan Agama dan Negara: Konteks Ke-Indonesiaan", Jurnal Politik Profetik, Vol. 4, No. 2, 2014.

Adawiyah, Rubiyatul, M. Mansur, Trisakti Handayani, “Analisis Penerapan Pendidikan Multikultural Dalam Menciptakan Toleransi Antar Umat Beragama”, Jurnal Civic Hukum, Vol. 4, No. 1, 2019.

Benuf, Kornelius, and Muhamad Azhar, 'Metodologi Penelitian Hukum Sebagai Instrumen Mengurai Permasalahan Hukum Kontemporer', Gema Keadilan, 7.1 (2020), 20-33

Hermawati, Rina, Caroline Paskarina, dan NunungRuniawati, "Toleransi Antar Umat Beragama di Kota Bandung”, Jurnal Umbara, Vol. 1, No. 2, 2016.

Junita, DianNingrum, Suryadi, dan Dian Eka Chandra Wardhana, "Kajian Ujaran Kebencian Di Media Sosial”, Jurnal Ilmiah Korpus, Vol. 2, No. 3, 2018.

Kambali, Muhammad, "Paradigma Sistem Kapitalisme dan Islam Tentang Welfare State", Jurnal JES, Vol. 3, No. 2, 2019. 


\begin{tabular}{llrr}
\hline \hline Volume: & 3 & E-ISSN: & 2655-1942 \\
Number: & 1 & Terbitan: & April 2020 \\
Page : & $42-56$ & & \\
\hline
\end{tabular}

Latifah dan Dinda Larasati, "Demokrasi dan Organisasi Masyarakat Sipil: Malang Corruption Watch”, Jurnal Sospol, Vol. 4, No. 1, 2018.

Latuconsina, Nuraini, "Perkembangan Demokrasi dan Civil Society di Indonesia". Jurnal Populis, Vol. 7, No. 2, 2013.

Lestari, Gina, "Bhinnekha Tunggal Ika: Khasanah Multikultural Indonesia Di Tengah Kehidupan Sara”, Jurnal Pendidikan Pancasila dan Kewarganegaraan, Vol. 28, No. 1, 2015.

Marzali, Amri, “Agama dan Kebudayaan”, Jurnal Umbara, Vol. 1, No. 1, 2016.

Nasrudin, Juhana dan Ahmad Ali Nurdin, "Politik Identitas dan Representasi Politik (Studi Kasus Pada Pilkada DKI Periode 2018-2022)”, Jurnal Hanifiya, Vol. 1, No. 1, 2018.

Prolensia, Carolina dan Don BoscoKarnanArdijanto, "Pemahaman Umat Katolik Di Stasi ST. Yosef Karangrejo, Paroki Regina PacisMagetan Tentang Kebangkitan Badan dan Kehidupan Kekal dalam Ajaran Gereja Katolik", Jurnal Pendidikan Agama Katolik, Vol. 20, No. 10, 2018.

Purnamasari, Galuh Candra, "Problematik Penerapan Aturan Pembatasan Hak Asasi Manusia dalam Konstitusi Indonesia”, Jurnal Prioris,Vol. 6, No. 2, 2017.

Volka, Anthony A.,KaterinaSchirallia, XiaoyangXiab, JunruZhaoc, dan Andrew V. Dane, "Adolescent bullying and personality: A cross-cultural approach", Personality and Individual Differences Journal, Vol. 125, Vol. 1, 2018.

\section{Peraturan Perundang-undangan:}

Deklarasi Universal Hak-Hak Asasi Manusia 1948.

Kovenan Internasional tentang Hak-hak Sipil dan Politik 1966.

Undang-Undang Dasar Negara Republik Indonesia 1945. 


\section{Law, Development \& Justice Review}

\begin{tabular}{llrr}
\hline \hline Volume: & 3 & E-ISSN: & $2655-1942$ \\
Number: & 1 & Terbitan: & April 2020 \\
Page : & $42-56$ & & \\
\hline
\end{tabular}

Undang-Undang Nomor 39 tahun 1999 tentang Hak Asasi Manusia (Lembaran Negara Republik Indonesia Tahun 1999 Nomor 165, Tambahan Lembaran Negara Republik Indonesia Nomor 3886) 